\title{
Pengaruh Mulsa Terhadap Pertumbuhan dan Hasil Kultivar Terung Lokal (Solanum Melongena, L.)
}

\author{
Krisantus Tri ${ }^{\mathrm{a}}$, Theodorus Kefi ${ }^{\mathrm{b}}$ \\ ${ }^{a}$ Fakultas Pertanian, Universitas Timor, Kefamenanu, TTU - NTT, 85613, Indonesia. \\ ${ }^{b}$ Fakultas Pertanian, Universitas Timor, Kefamenanu, TTU - NTT, 85613, Indonesia.
}

\section{Article Info}

\section{Article history:}

Received 27 Agustus 2015

Received in revised form 1 September 2015

Accepted 30 September 2015

\section{Keywords:}

Kultivar Terung Lokal

Mulsa

\begin{abstract}
Abstrak
Penggunaan mulsa bertujuan untuk mempertahankan suhu tanah, kelembaban tanah, kandungan bahan organik, mengurangi jumlah dan kecepatan aliran permukaan, meningkatkan penyerapan air, dan menekan pertumbuhan gulma, sehingga dapat tersedia kondisi lingkungan yang optimum bagi pertumbuhan tanaman. Selain itu diduga beberapa kultivar lokal memiliki tanggapan berbeda terhadap penggunaan mulsa. Percobaan lapangan dilaksanakan untuk mempelajari pengaruh mulsa terhadap pertumbuhan dan hasil kultivar terung lokal di kebun percobaan Fakultas Pertanian, Universitas Timor, Kefamenanu, Kabupaten Timor Tengah Utara, NTT, menggunakan Rancangan Petak Berjalur (Strip Plot Design) 3 x 3 diulang 3 kali. Faktor pertama adalah kultivar terung (kualoto) lokal yaitu; buah bulat kecil (fua bubu ana), buah bulat besar (fua bubu naek) dan buah bulat panjang (fua bubu mnanu). Faktor kedua adalah Mulsa yaitu; dari alang-alang, plastik hitam, dan tanpa mulsa. Hasil Penelitian menyimpulkan bahwa semua kultivar terung lokal cocok pada lahan yang ditutupi mulsa alang-alang dan hasil tertinggi diperoleh terung lokal buah bulat panjang. Pada lahan tanpa mulsa, maupun yang ditutupi mulsa plastik, kultivar terung lokal buah bulat besar beradaptasi lebih baik. (O2016 dipubikasikan oleh Savana Cendana.
\end{abstract}

\section{Pendahuluan}

Bisnis terung lokal kultivar bulat panjang masih memberikan peluang pasar yang cukup baik bahkan sampai menembus pasar ekspor. Permintaannya terung terus meningkat, ditunjukan oleh meluasnya daerah pemasaran dari pasar tradisional, supermarket hingga dijadikan bahan komoditas ekspor (Hastuti, 2007)

Memodifikasi iklim mikro di sekitar tanaman hortikultura merupakan upaya yang telah banyak dilakukan agar tanaman dapat tumbuh, berkembang dan hasilnya meningkat. Kelembaban udara dan tanah merupakan komponen iklim mikro yang sangat mempengaruhi pertumbuhan tanaman dan masing-masing berkaitan dalam mewujudkan keadaan lingkungan yang optimal bagi pertumbuhan tanaman. Mulsa merupakan bahan yang potensial untuk mempertahankan suhu tanah, kelembaban tanah, kandungan bahan organik, mengurangi jumlah dan kecepatan aliran permukaan, meningkatkan penyerapan air, dan menekan pertumbuhan gulma. Bahan-bahan yang dapat digunakan sebagai mulsa adalah bahan anorganik seperti plastik hitam maupun bahan organik seperti jerami padi dan alang-alang (Noorhadi dan Sudadi, 2003). Permasalahannya adalah belum diketahui seberapa besar pengaruh jenis mulsa terhadap beberapa kultivar terung lokal dalam meningkatkan pertumbuhan dan hasil. Untuk itu perlu melakukan penelitian tentang pengaruh kombinasi mulsa terhadap pertumbuhan dan hasil verietas terung lokal. Diduga Pemberian mulsa alang-alang pada kultivar terung lokal mampu memberikan pertumbuhan dan hasil paling baik.

\section{Metode}

Penelitian dilaksanakan bulan November 2010 - April 2011 di Kampus Fakultas Pertanian UNIMOR, Kelurahan Sasi, Kefamenanu, Kabupaten Timor Tengah Utara, NTT. Topografi berbukit dengan ketinggian $300-400 \mathrm{~m} \mathrm{dpl}$ curah hujan $900-1500 \mathrm{~mm}$ per tahun. Suhu udara berkisar antara $27-34{ }^{\circ} \mathrm{C}$ dan $\mathrm{pH}$ tanah netral $(6,5)$ (BPS TTU, 2007). Percobaan lapangan menggunakan Rancangan Petak Berjalur (Strip Plot Design) 3 x 3 diulang 3 kali. Faktor pertama adalah Kultivar Terung (kauloto) Lokal (V) yang terdiri dari 3 aras yakni kultivar bulat kecil $\left(\mathrm{v}_{1}\right)$, kultivar bulat besar $\left(\mathrm{v}_{2}\right)$, kultivar bulat panjang $\left(\mathrm{v}_{3}\right)$. Faktor kedua adalah Mulsa (M) yang terdiri dari 3 aras yakni mulsa plastik hitam $\left(\mathrm{m}_{1}\right)$, tanpa mulsa $\left(\mathrm{m}_{2}\right)$ dan mulsa alang-alang $\left(\mathrm{m}_{3}\right)$. Kombinasi perlakuannya adalah $\mathrm{v}_{1} \mathrm{~m}_{1}$, $\mathrm{v}_{1} \mathrm{~m}_{2}, \mathrm{v}_{1} \mathrm{~m}_{3}, \mathrm{v}_{2} \mathrm{~m}_{1}, \mathrm{v}_{2} \mathrm{~m}_{2}, \mathrm{v}_{2} \mathrm{~m}_{3}, \mathrm{v}_{3} \mathrm{~m}_{1}, \mathrm{v}_{3} \mathrm{~m}_{2}$ dan $\mathrm{v}_{3} \mathrm{~m}_{3}$

Memulai penelitian dengan persiapan benih kultivar kauloto (terung) kultivar terung bulat kecil, terung buah bulat besar, terung buah bulat panjang berasal dari petani yang berada di 3 titik lokasi: Desa Bokon, Kaenbaun dan desa Banain Kecamatan Miomaffo Timur, dari buah yang cukup matang, mengambil bijinya kemudian menjemurnya selama 1 minggu. Selanjutnya meseleksi benih bernas yaitu memilih biji yang sehat atau tidak cacat sebanyak-banyaknya dengan cara merendamnya dalam air pada 3 ember terpisah sesuai dengan jenis kultivar tersebut, dan biji yang terapung dibuang.

Menyiapkan lahan dengan cara pembersihan, olah tanah yaitu membuat bedeng 5,4 m2 (1,8 x $3 \mathrm{~m})$ sebanyak 27 dalam 3 blok. Penyiapan lubang ukuran $20 \times 20 \times 20 \mathrm{~cm}$ pada jarak tanam $60 \times 60 \mathrm{~cm}$. Penyemaian dengan cara membuat 3 petak persemaian awal untuk setiap kultivar secara terpisah dengan luas tiap petak 1 x 1 m. 3 minggu setelah semai bibit dipindah ke polibag ukuran 10 x 15 cm (Rukmana, 1994) dipelihara terpisah sesuai kultivarnya hingga umur 6 minggu.

Pemulsaan plastik dilakukan dengan cara membentang mulsa plastik kemudian melubanginya sesuai dengan jarak tanam. Pemulsaan alang-alang dengan cara membentangnya pada lahan dan melubanginya sesuai dengan jarak tanam (Samadi, 2001). Selanjutnya penggemburan lubang tanam, menanam bibit terung yang berdaun 3 - 4 helai (umur 6 minggu) menempatkannya sesuai label perlakuan. Pemeliharaan meliputi; penyiraman, pemupukan, pemulsaan, penyulaman, penyiangan, panen
Pengamatan meliputi: suhu tanah, kadar lengas tanah, berat volume tanah, tinggi tanaman, diameter batang jumlah daun, luas daun, bobot kering berangkasan, berat segar buah per petak, jumlah buah per petak, indeks panen.

Analisa data hasil pengamatan dengan menggunakan sidik ragam (Anova) Rancangan Petak Berjalur (Strip Plot Design) untuk mengetahui ada tidaknya interaksi antara faktor perlakuan dan untuk mengetahui perbedaan antara rerata perlakuan menggunakan taraf nyata $(\alpha)$ 0,05 menurut Uji Beda Jarak Ganda Duncan (Duncan Multiple Range Test) (Adji, 2000; Hanafiah, 2005).

\section{Hasil dan Pembahasan}

Interaksi antar perlakuan menunjukkan bahwa, suhu tanah dari petak antar kultivar tidak berbeda nyata saat pengamatan 15, 45 dan 75 HST, tetapi suhu tanah pada petak tanpa mulsa lebih tinggi dan berbeda nyata dibanding dengan petak yang diberi perlakuan mulsa. Suhu terendah terjadi pada petak yang diberi perlakuan mulsa alang-alang dengan kultivar buah bulat panjang.

Interaksi menunjukkan kadar lengas tanah pada petak antar kultivar tidak berbeda nyata pada setiap waktu pengamatan. Interaksi optimum untuk kadar lengas 15, 45 dan 75 HST antara perlakuan mulsa pada kultivar buah bulat kecil dengan mulsa alang alang, pada kultivar buah bulat besar dengan mulsa plastik hitam sedangkan pada kultivar buah bulat panjang dengan mulsa alang-alang.

Interaksi nyata terjadi pada setiap waktu pengamatan berat volume tanah. Pengaruh tunggal perlakuan mulsa tidak nyata pada pengamatan 15 HST. Sidik ragam 15, 45 dan 75 HST menunjukkan bahwa interaksi optimum terjadi antara perlakuan kultivar buah bulat kecil dengan mulsa plastik hitam, antara perlakuan kultivar buah bulat besar dengan mulsa alang-alang, dan antara kultivar buah bulat panjang dengan mulsa plastik hitam.

Interaksi antara kultivar, tidak nyata pada setiap waktu pengamatan terhadap tinggi tanaman. Interaksi optimum untuk tinggi tanaman 15, 45 dan 75 HST antara perlakuan mulsa pada kultivar buah bulat besar dengan mulsa alang-alang, antara perlakuan kultivar buah bulat panjang dengan mulsa alang-alang, dan antara perlakuan kultivar buah bulat kecil pada perlakuan mulsa plastik hitam.

Interaksi antara kultivar buah bulat kecil dan antara kultivar buah bulat besar tidak beda nyata namun antara kultivar buah bulat panjang menunjukkan berbeda nyata pada perlakuan mulsa alang-alang pada waktu pengamatan 15 dan 45 HST dan tetapi pada 75 HST tidak ada beda nyata.

Sidik ragam 15,45 , dan 75 HST menunjukan interaksi optimum terjadi antara perlakuan kultivar buah bulat besar pada mulsa alang - alang, antara perlakuan kultivar buah bulat kecil pada perlakuan mulsa plastik, dan pada perlakuan kultivar buah bulat kecil pada perlakuan tanpa mulsa.

Interaksi terhadap jumlah daun antara kultivar pada semua pengamatan yakni 15, 45, dan 75 HST menunjukan bahwa pada perlakuan kultivar buah bulat panjang pada mulsa alang-alang berbeda nyata dibanding perlakuan kultivar buah bulat kecil dan kultivar buah bulat besar. Interaksi optimum terjadi pada semua pengamatan jumlah daun yakni pada perlakuan kultivar buah bulat kecil dengan perlakuan mulsa plastik hitam.

Interaksi antara perlakuan kultivar dan pemberian mulsa terhadap luas daun pada setiap waktu pengamatan berbeda sangat nyata. Sidik ragam 15, 45, dan 75 HST menunjukan bahwa interaksi optimum antara perlakuan kultivar buah bulat besar dengan pemberian mulsa plastik hitam, antara perlakuan kultivar buah bulat panjang dengan pemberian mulsa alang-alang, dan antara perlakuan kultivar buah bulat kecil dengan perlakuan mulsa plastik hitam.

Interaksi antara kultivar pada pengamatan jumlah buah tidak beda nyata dengan pemberian mulsa pada setiap waktu panen. Interaksi optimum pada pengamatan jumlah buah terjadi antara perlakuan kultivar buah bulat panjang dengan pemberian mulsa alang-alang.

Interaksi antara kultivar pada penimbangan berat kering berangkasan menunjukkan beda nyata antara perlakuan kultivar buah bulat panjang dengan pemberian mulsa alang-alang. Interaksi optimum terjadi pada perlakuan kultivar alang-alang dengan pemberian mulsa alang-alang. 
Interaksi antara kultivar terhadap berat buah menunjukan tidak berbeda nyata pada pemberian mulsa pada disetiap waktu panen. Interaksi optimum

Tabel 1. Suhu Tanah $\left({ }^{\circ} \mathrm{C}\right)$

\begin{tabular}{|c|c|c|c|c|c|}
\hline \multirow[b]{2}{*}{ Waktu } & \multirow[b]{2}{*}{ Mulsa } & \multicolumn{3}{|c|}{ Kultivar } & \multirow[b]{2}{*}{ Rerata } \\
\hline & & $\begin{array}{c}\text { Buah Bulat } \\
\text { Kecil }\end{array}$ & $\begin{array}{c}\text { Buah Bulat } \\
\text { Besar }\end{array}$ & $\begin{array}{c}\text { Buah Bulat } \\
\text { Panjang }\end{array}$ & \\
\hline \multirow{7}{*}{15 HST } & \multirow{2}{*}{ Tanpa } & $37,69 \mathrm{pa}$ & $36,92 \mathrm{pa}$ & $37,18 \mathrm{pa}$ & 36,26 \\
\hline & & xa & ya & $\mathrm{za}$ & $\mathrm{a}$ \\
\hline & \multirow{2}{*}{$\begin{array}{l}\text { Plastik } \\
\text { Hitam }\end{array}$} & 30,22 qa & $26,81 \mathrm{qa}$ & 26,78 qa & 27,94 \\
\hline & & $\mathrm{xb}$ & $\mathrm{yb}$ & $\mathrm{zb}$ & $\mathrm{b}$ \\
\hline & \multirow{2}{*}{$\begin{array}{l}\text { Alang- } \\
\text { Alang }\end{array}$} & $29,33 \mathrm{ra}$ & $27,44 \mathrm{ra}$ & $25,55 \mathrm{ra}$ & 27,44 \\
\hline & & $\mathrm{xb}$ & $\mathrm{yb}$ & $\mathrm{zb}$ & $\mathrm{b}$ \\
\hline & Rerata & $32,41 \mathrm{a}$ & 29,39 a & 29,84 a & \\
\hline \multirow{7}{*}{45 HST } & \multirow{2}{*}{ Tanpa } & $37,50 \mathrm{pa}$ & 33,73 pa & $36,99 \mathrm{pa}$ & 36,07 \\
\hline & & xa & ya & $\mathrm{za}$ & $\mathrm{a}$ \\
\hline & \multirow{2}{*}{$\begin{array}{l}\text { Plastik } \\
\text { Hitam }\end{array}$} & 30,03 qa & 26,62 qa & 26,59 qa & 27,75 \\
\hline & & $\mathrm{xb}$ & $\mathrm{yb}$ & $\mathrm{zb}$ & b \\
\hline & \multirow{2}{*}{$\begin{array}{l}\text { Alang- } \\
\text { Alang }\end{array}$} & $29,14 \mathrm{ra}$ & $27,25 \mathrm{ra}$ & $25,36 \mathrm{ra}$ & 27,25 \\
\hline & & $\mathrm{xb}$ & $\mathrm{yb}$ & $\mathrm{zb}$ & $\mathrm{b}$ \\
\hline & Rerata & $32,23 \mathrm{a}$ & $29,20 \mathrm{a}$ & $29,65 \mathrm{a}$ & \\
\hline \multirow{7}{*}{75 HST } & \multirow{2}{*}{ Tanpa } & $39,69 \mathrm{pa}$ & $35,92 \mathrm{pa}$ & $39,18 \mathrm{pa}$ & 38,26 \\
\hline & & xa & ya & $\mathrm{za}$ & $\mathrm{a}$ \\
\hline & \multirow{2}{*}{$\begin{array}{l}\text { Plastik } \\
\text { Hitam }\end{array}$} & 32,22 qa & $28,81 \mathrm{qa}$ & 28,78 qa & 29,94 \\
\hline & & $\mathrm{xb}$ & $\mathrm{yb}$ & $\mathrm{zb}$ & $\mathrm{b}$ \\
\hline & \multirow{2}{*}{$\begin{array}{l}\text { Alang- } \\
\text { Alang }\end{array}$} & $31,33 \mathrm{ra}$ & $29,44 \mathrm{ra}$ & $27,55 \mathrm{ra}$ & 29,44 \\
\hline & & $\mathrm{xb}$ & $\mathrm{yb}$ & $\mathrm{zb}$ & $\mathrm{b}$ \\
\hline & Rerata & $34,42 \mathrm{a}$ & $31,39 \mathrm{a}$ & $31,84 \mathrm{a}$ & \\
\hline Keterang & $\begin{array}{l}\text { Ang } \\
\text { tara } \\
(+)\end{array}$ & $\begin{array}{l}\text { ada kolom de } \\
\text { ta }(\alpha) 5 \% \text { me } \\
\text { jadi interaks }\end{array}$ & $\begin{array}{l}\text { aris diikuti hu } \\
\text { ut uji DMRT } \\
\text { tar perlakuan }\end{array}$ & & a pada \\
\hline
\end{tabular}

Tabel 2. Kadar Lengas tanah $(\%)$

\begin{tabular}{|c|c|c|c|c|c|}
\hline \multirow[b]{2}{*}{ Waktu } & \multirow[b]{2}{*}{ Mulsa } & \multicolumn{3}{|c|}{ Kultivar } & \multirow[b]{2}{*}{ Rerata } \\
\hline & & $\begin{array}{c}\text { Buah Bulat } \\
\text { Kecil }\end{array}$ & $\begin{array}{c}\text { Buah Bulat } \\
\text { Besar }\end{array}$ & $\begin{array}{c}\text { Buah Bulat } \\
\text { Panjang }\end{array}$ & \\
\hline \multirow{7}{*}{15 HST } & \multirow{2}{*}{ Tanpa } & $14,59 \mathrm{pa}$ & 17,75 pa & $17,26 \mathrm{pa}$ & 16,54 \\
\hline & & xa & ya & $\mathrm{za}$ & a \\
\hline & \multirow{2}{*}{$\begin{array}{c}\text { Plastik } \\
\text { Hitam }\end{array}$} & $20,88 \mathrm{qa}$ & $25,20 \mathrm{qa}$ & 23,54 qa & 23,21 \\
\hline & & $\mathrm{xb}$ & $\mathrm{yb}$ & $\mathrm{zb}$ & $\mathrm{b}$ \\
\hline & \multirow{2}{*}{$\begin{array}{l}\text { Alang- } \\
\text { Alang }\end{array}$} & $22,06 \mathrm{ra}$ & $22,30 \mathrm{ra}$ & $24,92 \mathrm{ra}$ & 23,10 \\
\hline & & $\mathrm{xb}$ & $\mathrm{yb}$ & $\mathrm{zb}$ & b \\
\hline & Rerata & $19,18 \mathrm{a}$ & $21,75 \mathrm{a}$ & $21,91 \mathrm{a}$ & (+) \\
\hline \multirow{7}{*}{45 HST } & \multirow{2}{*}{ Tanpa } & $14,95 \mathrm{pa}$ & 18,11 pa & $17,62 \mathrm{pa}$ & 16,89 \\
\hline & & xa & ya & $\mathrm{za}$ & a \\
\hline & \multirow{2}{*}{$\begin{array}{l}\text { Plastik } \\
\text { Hitam }\end{array}$} & $21,24 \mathrm{qa}$ & $25,56 \mathrm{qa}$ & $23,89 \mathrm{qa}$ & 23,56 \\
\hline & & $\mathrm{xb}$ & $\mathrm{yb}$ & $\mathrm{zb}$ & b \\
\hline & \multirow{2}{*}{$\begin{array}{l}\text { Alang- } \\
\text { Alang }\end{array}$} & $22,42 \mathrm{ra}$ & $22,66 \mathrm{ra}$ & $25,28 \mathrm{ra}$ & 23,45 \\
\hline & & $\mathrm{xb}$ & $\mathrm{yb}$ & $\mathrm{zb}$ & $\mathrm{b}$ \\
\hline & Rerata & $19,53 \mathrm{a}$ & $22,11 \mathrm{a}$ & $22,26 \mathrm{a}$ & $(+)$ \\
\hline \multirow{7}{*}{75 HST } & \multirow{2}{*}{ Tanpa } & 14,48 pa & $17,64 \mathrm{pa}$ & 17,15 pa & 16,42 \\
\hline & & xa & ya & $\mathrm{za}$ & $\mathrm{a}$ \\
\hline & \multirow{2}{*}{$\begin{array}{l}\text { Plastik } \\
\text { Hitam }\end{array}$} & $20,77 \mathrm{qa}$ & 25,09 qa & 23,43 qa & 23,09 \\
\hline & & $\mathrm{xb}$ & $\mathrm{yb}$ & $\mathrm{zb}$ & b \\
\hline & \multirow{2}{*}{$\begin{array}{l}\text { Alang- } \\
\text { Alang }\end{array}$} & $21,95 \mathrm{ra}$ & $22,19 \mathrm{ra}$ & $24,81 \mathrm{ra}$ & 22,98 \\
\hline & & $\mathrm{xb}$ & $\mathrm{yb}$ & $\mathrm{zb}$ & b \\
\hline & Rerata & 19,07 a & $21,64 \mathrm{a}$ & $21,80 \mathrm{a}$ & $(+)$ \\
\hline
\end{tabular}

terjadi antara perlakuan kultivar buah bulat panjang dengan pemberian mulsa alang-alang.

$\underline{\text { Tabel 3. Berat Volume Tanah }\left(\mathrm{g} / \mathrm{cm}^{3}\right)}$

\begin{tabular}{|c|c|c|c|c|c|}
\hline \multirow[b]{2}{*}{ Waktu } & \multirow[b]{2}{*}{ Mulsa } & \multicolumn{3}{|c|}{ Kultivar } & \multirow[b]{2}{*}{ Rerata } \\
\hline & & $\begin{array}{c}\text { Buah Bulat } \\
\text { Kecil }\end{array}$ & $\begin{array}{c}\text { Buah Bulat } \\
\text { Besar }\end{array}$ & $\begin{array}{c}\text { Buah Bulat } \\
\text { Panjang }\end{array}$ & \\
\hline \multirow{7}{*}{15 HST } & \multirow{2}{*}{ Tanpa } & 1,63 pa & $1,57 \mathrm{pa}$ & $1,67 \mathrm{pa}$ & 1,62 \\
\hline & & ха & yab & $\mathrm{zb}$ & b \\
\hline & \multirow{2}{*}{$\begin{array}{l}\text { Plastik } \\
\text { Hitam }\end{array}$} & $1,30 \mathrm{qa}$ & 1,59 qa & $1,27 \mathrm{qa}$ & 1,38 \\
\hline & & xa & $\mathrm{yb}$ & $\mathrm{za}$ & $\mathrm{a}$ \\
\hline & \multirow{2}{*}{$\begin{array}{l}\text { Alang- } \\
\text { Alang }\end{array}$} & $1,36 \mathrm{ra}$ & $1,35 \mathrm{ra}$ & $1,36 \mathrm{ra}$ & 1,36 \\
\hline & & ха & ya & za & $\mathrm{a}$ \\
\hline & Rerata & $1,43 \mathrm{a}$ & $1,50 \mathrm{a}$ & $1,43 \mathrm{a}$ & $(+)$ \\
\hline \multirow{7}{*}{45 HST } & \multirow{2}{*}{ Tanpa } & $1,27 \mathrm{pa}$ & $1,21 \mathrm{pa}$ & $1,31 \mathrm{pa}$ & 1,27 \\
\hline & & $\mathrm{xb}$ & yab & $\mathrm{zb}$ & $\mathrm{a}$ \\
\hline & \multirow{2}{*}{$\begin{array}{l}\text { Plastik } \\
\text { Hitam }\end{array}$} & 0,94 qa & $1,23 \mathrm{qb}$ & 0,91 qa & 1,03 \\
\hline & & xa & $\mathrm{yb}$ & $\mathrm{za}$ & a \\
\hline & \multirow{2}{*}{$\begin{array}{l}\text { Alang- } \\
\text { Alang }\end{array}$} & $1,01 \mathrm{ra}$ & $0,99 \mathrm{ra}$ & $1,01 \mathrm{ra}$ & 1,00 \\
\hline & & ха & ya & za & $\mathrm{a}$ \\
\hline & Rerata & $1,07 \mathrm{a}$ & $1,14 \mathrm{a}$ & $1,08 \mathrm{a}$ & $(+)$ \\
\hline \multirow{7}{*}{75 HST } & \multirow{2}{*}{ Tanpa } & $1,18 \mathrm{pa}$ & $1,12 \mathrm{pa}$ & $1,22 \mathrm{pa}$ & 1,18 \\
\hline & & $\mathrm{xb}$ & ya & $\mathrm{zb}$ & $\mathrm{a}$ \\
\hline & \multirow{2}{*}{$\begin{array}{l}\text { Plastik } \\
\text { Hitam }\end{array}$} & 0,85 qa & $1,14 \mathrm{qb}$ & 0,82 qa & 0,94 \\
\hline & & xa & ya & $\mathrm{za}$ & $\mathrm{a}$ \\
\hline & \multirow{2}{*}{$\begin{array}{l}\text { Alang- } \\
\text { Alang }\end{array}$} & $0,92 \mathrm{ra}$ & $0,90 \mathrm{ra}$ & $0,92 \mathrm{ra}$ & 0,91 \\
\hline & & xa & ya & za & $\mathrm{a}$ \\
\hline & Rerata & $0,98 \mathrm{a}$ & $1,05 \mathrm{a}$ & $0,99 \mathrm{a}$ & $(+)$ \\
\hline
\end{tabular}

Tabel 4. Tinggi Tanaman $(\mathrm{cm})$

\begin{tabular}{|c|c|c|c|c|c|}
\hline \multirow[b]{2}{*}{ Waktu } & \multirow[b]{2}{*}{ Mulsa } & \multicolumn{3}{|c|}{ Kultivar } & \multirow[b]{2}{*}{ Rerata } \\
\hline & & $\begin{array}{c}\text { Buah Bulat } \\
\text { Kecil }\end{array}$ & $\begin{array}{c}\text { Buah Bulat } \\
\text { Besar }\end{array}$ & $\begin{array}{c}\text { Buah Bulat } \\
\text { Panjang }\end{array}$ & \\
\hline \multirow{7}{*}{15 HST } & \multirow{2}{*}{ Tanpa } & 7,34 pa & $7,09 \mathrm{pa}$ & 5,77 ра & 6,73 \\
\hline & & xa & ya & $\mathrm{za}$ & $\mathrm{a}$ \\
\hline & \multirow{2}{*}{$\begin{array}{l}\text { Plastik } \\
\text { Hitam }\end{array}$} & 8,19 qa & 7,54 qa & $6,98 \mathrm{qa}$ & 7,57 \\
\hline & & xa & ya & $\mathrm{za}$ & $\mathrm{a}$ \\
\hline & \multirow{2}{*}{$\begin{array}{l}\text { Alang- } \\
\text { Alang }\end{array}$} & $6,81 \mathrm{rb}$ & $10,02 \mathrm{ra}$ & $7,22 \mathrm{rb}$ & 8,02 \\
\hline & & xa & ya & $\mathrm{za}$ & $\mathrm{a}$ \\
\hline & Rerata & $7,45 \mathrm{a}$ & $8,22 \mathrm{a}$ & $6,66 \mathrm{a}$ & $(+)$ \\
\hline \multirow{7}{*}{45 HST } & \multirow{2}{*}{ Tanpa } & $23,09 \mathrm{pa}$ & $29,32 \mathrm{pa}$ & $27,58 \mathrm{pa}$ & 26,66 \\
\hline & & xa & ya & $\mathrm{za}$ & a \\
\hline & \multirow{2}{*}{$\begin{array}{l}\text { Plastik } \\
\text { Hitam }\end{array}$} & $36,41 \mathrm{qa}$ & $27,93 \mathrm{qb}$ & $32,02 \mathrm{qab}$ & 32,12 \\
\hline & & $\mathrm{xb}$ & ya & $\mathrm{za}$ & a \\
\hline & \multirow{2}{*}{$\begin{array}{l}\text { Alang- } \\
\text { Alang }\end{array}$} & $40,03 \mathrm{ra}$ & $38,81 \mathrm{ra}$ & $41,40 \mathrm{ra}$ & 40,08 \\
\hline & & $\mathrm{xb}$ & $\mathrm{yb}$ & $\mathrm{zb}$ & b \\
\hline & Rerata & $33,18 \mathrm{a}$ & $32,02 \mathrm{a}$ & $33,67 \mathrm{a}$ & $(+)$ \\
\hline \multirow{7}{*}{75 HST } & \multirow{2}{*}{ Tanpa } & $23,09 \mathrm{pa}$ & $29,32 \mathrm{pa}$ & $27,58 \mathrm{pa}$ & 26,66 \\
\hline & & $\mathrm{xa}$ & ya & $\mathrm{za}$ & $\mathrm{a}$ \\
\hline & \multirow{2}{*}{$\begin{array}{l}\text { Plastik } \\
\text { Hitam }\end{array}$} & $41,41 \mathrm{qa}$ & 37,27 qa & 37,02 qa & 38,57 \\
\hline & & $\mathrm{xb}$ & yab & $\mathrm{zb}$ & b \\
\hline & \multirow{2}{*}{$\begin{array}{l}\text { Alang- } \\
\text { Alang }\end{array}$} & $40,03 \mathrm{ra}$ & $38,81 \mathrm{ra}$ & $41,40 \mathrm{ra}$ & 40,08 \\
\hline & & $\mathrm{xb}$ & $\mathrm{yb}$ & $\mathrm{zb}$ & b \\
\hline & Rerata & $34,84 \mathrm{a}$ & $35,13 \mathrm{a}$ & $35,33 \mathrm{a}$ & $(+)$ \\
\hline
\end{tabular}


Tabel 5. Diameter Batang $(\mathrm{cm})$

\begin{tabular}{|c|c|c|c|c|c|}
\hline \multirow[b]{2}{*}{ Waktu } & \multirow[b]{2}{*}{ Mulsa } & \multicolumn{3}{|c|}{ Kultivar } & \multirow[b]{2}{*}{ Rerata } \\
\hline & & $\begin{array}{c}\text { Buah Bulat } \\
\text { Kecil }\end{array}$ & $\begin{array}{c}\text { Buah Bulat } \\
\text { Besar }\end{array}$ & $\begin{array}{c}\text { Buah Bulat } \\
\text { Panjang }\end{array}$ & \\
\hline \multirow{7}{*}{15 HST } & \multirow{2}{*}{ Tanpa } & $0,21 \mathrm{pa}$ & 0,23 pa & $0,19 \mathrm{pa}$ & 0,21 \\
\hline & & $\mathrm{xa}$ & ya & $\mathrm{za}$ & a \\
\hline & \multirow{2}{*}{$\begin{array}{l}\text { Plastik } \\
\text { Hitam }\end{array}$} & 0,23 qa & $0,20 \mathrm{qa}$ & 0,16 qa & 0,20 \\
\hline & & xa & ya & $\mathrm{za}$ & $\mathrm{a}$ \\
\hline & \multirow{2}{*}{$\begin{array}{l}\text { Alang- } \\
\text { Alang }\end{array}$} & $0,20 \mathrm{rb}$ & $0,28 \mathrm{ra}$ & $0,16 \mathrm{rb}$ & 0,21 \\
\hline & & $\mathrm{xa}$ & ya & $\mathrm{za}$ & $\mathrm{a}$ \\
\hline & Rerata & $0,21 \mathrm{a}$ & $0,24 \mathrm{a}$ & $0,17 \mathrm{~b}$ & $(-)$ \\
\hline \multirow{7}{*}{45 HST } & \multirow{2}{*}{ Tanpa } & $0,70 \mathrm{pa}$ & 0,74 pa & $0,56 \mathrm{pa}$ & 0,67 \\
\hline & & $\mathrm{xa}$ & ya & $\mathrm{za}$ & $\mathrm{a}$ \\
\hline & \multirow{2}{*}{$\begin{array}{l}\text { Plastik } \\
\text { Hitam }\end{array}$} & 0,75 qa & $0,56 \mathrm{qb}$ & $0,49 \mathrm{qb}$ & 0,60 \\
\hline & & $\mathrm{xa}$ & ya & $\mathrm{za}$ & $\mathrm{a}$ \\
\hline & \multirow{2}{*}{$\begin{array}{l}\text { Alang- } \\
\text { Alang }\end{array}$} & $0,66 \mathrm{ra}$ & $0,64 \mathrm{ra}$ & $0,52 \mathrm{ra}$ & 0,61 \\
\hline & & xa & ya & $\mathrm{za}$ & $\mathrm{a}$ \\
\hline & Rerata & $0,70 \mathrm{a}$ & $0,65 \mathrm{a}$ & $0,52 \mathrm{~b}$ & $(-)$ \\
\hline \multirow{7}{*}{75 HST } & \multirow{2}{*}{ Tanpa } & $0,94 \mathrm{pa}$ & $0,98 \mathrm{pa}$ & $0,80 \mathrm{pa}$ & 0,91 \\
\hline & & $\mathrm{xa}$ & ya & $\mathrm{za}$ & $\mathrm{a}$ \\
\hline & \multirow{2}{*}{$\begin{array}{l}\text { Plastik } \\
\text { Hitam }\end{array}$} & $0,83 \mathrm{qa}$ & $0,80 \mathrm{qa}$ & 0,73 qa & 0,78 \\
\hline & & xa & ya & $\mathrm{za}$ & $\mathrm{a}$ \\
\hline & \multirow{2}{*}{$\begin{array}{l}\text { Alang- } \\
\text { Alang }\end{array}$} & $0,90 \mathrm{ra}$ & $0,88 \mathrm{ra}$ & $0,76 \mathrm{ra}$ & 0,85 \\
\hline & & xa & ya & $\mathrm{za}$ & $\mathrm{a}$ \\
\hline & Rerata & 0,89 a & 0,89 a & $0,76 \mathrm{a}$ & $(-)$ \\
\hline Keteran & \multicolumn{5}{|c|}{$\begin{array}{l}\text { Angka pada kolom dan baris diikuti huruf sama tidak berbeda pada } \\
\text { taraf nyata }(\alpha) 5 \% \text { menurut uji DMRT } \\
(+)=\text { Terjadi interaksi antar perlakuan }\end{array}$} \\
\hline
\end{tabular}

\section{Jumlah Daun}

Interaksi antara kultivar pada semua pengamatan yakni 15, 45, dan 75 HST menunjukan bahwa pada perlakuan kultivar buah bulat panjang pada mulsa alang-alang beda nyata dibanding perlakuan kultivar buah bulat kecil dan kultivar buah bulat besar.

Tabel 6. Jumlah Daun (helai)

\begin{tabular}{|c|c|c|c|c|c|}
\hline \multirow[b]{2}{*}{ Waktu } & \multirow[b]{2}{*}{ Mulsa } & \multicolumn{3}{|c|}{ Kultivar } & \multirow[b]{2}{*}{ Rerata } \\
\hline & & $\begin{array}{c}\text { Buah Bulat } \\
\text { Kecil }\end{array}$ & $\begin{array}{c}\text { Buah Bulat } \\
\text { Besar }\end{array}$ & $\begin{array}{c}\text { Buah Bulat } \\
\text { Panjang }\end{array}$ & \\
\hline \multirow{7}{*}{15 HST } & \multirow{2}{*}{ Tanpa } & $7,67 \mathrm{pa}$ & $7,00 \mathrm{pb}$ & $7,00 \mathrm{pb}$ & 7,22 \\
\hline & & xa & ya & $\mathrm{za}$ & $\mathrm{a}$ \\
\hline & \multirow{2}{*}{$\begin{array}{l}\text { Plastik } \\
\text { Hitam }\end{array}$} & $10,33 \mathrm{qa}$ & $9,33 \mathrm{qb}$ & $7,33 \mathrm{qb}$ & 9,00 \\
\hline & & $\mathrm{xb}$ & b & $\mathrm{za}$ & a \\
\hline & \multirow{2}{*}{$\begin{array}{l}\text { Alang- } \\
\text { Alang }\end{array}$} & $8,33 \mathrm{rb}$ & $9,00 \mathrm{ra}$ & $9,33 \mathrm{ra}$ & 8,89 \\
\hline & & xa & $\mathrm{yb}$ & $\mathrm{zb}$ & $\mathrm{a}$ \\
\hline & Rerata & $8,78 \mathrm{a}$ & $8,44 \mathrm{a}$ & $7,89 \mathrm{~b}$ & $(+)$ \\
\hline \multirow{7}{*}{45 HST } & \multirow{2}{*}{ Tanpa } & $9,97 \mathrm{pa}$ & $9,30 \mathrm{pb}$ & $9,30 \mathrm{pb}$ & 9,52 \\
\hline & & xa & ya & $\mathrm{za}$ & $\mathrm{a}$ \\
\hline & \multirow{2}{*}{$\begin{array}{l}\text { Plastik } \\
\text { Hitam }\end{array}$} & $12,63 \mathrm{qa}$ & $11,63 \mathrm{qb}$ & $9,63 \mathrm{qb}$ & 11,30 \\
\hline & & $\mathrm{xb}$ & $\mathrm{yb}$ & $\mathrm{za}$ & a \\
\hline & \multirow{2}{*}{$\begin{array}{l}\text { Alang- } \\
\text { Alang }\end{array}$} & $10,63 \mathrm{rb}$ & $11,30 \mathrm{ra}$ & $11,63 \mathrm{ra}$ & 11,19 \\
\hline & & $\mathrm{xb}$ & $\mathrm{yb}$ & $\mathrm{zb}$ & $\mathrm{a}$ \\
\hline & Rerata & $11,08 \mathrm{a}$ & $10,74 \mathrm{a}$ & $10,19 \mathrm{~b}$ & $(+)$ \\
\hline \multirow{7}{*}{75 HST } & \multirow{2}{*}{ Tanpa } & $24,97 \mathrm{pa}$ & $24,30 \mathrm{pb}$ & $24,30 \mathrm{pb}$ & 24,52 \\
\hline & & xa & ya & $\mathrm{za}$ & $\mathrm{a}$ \\
\hline & \multirow{2}{*}{$\begin{array}{l}\text { Plastik } \\
\text { Hitam }\end{array}$} & 27,63 qa & $26,63 \mathrm{qb}$ & $24,63 \mathrm{qb}$ & 26,30 \\
\hline & & $\mathrm{xb}$ & $\mathrm{yb}$ & $\mathrm{za}$ & $\mathrm{a}$ \\
\hline & \multirow{2}{*}{$\begin{array}{c}\text { Alang- } \\
\text { Alang }\end{array}$} & $25,63 \mathrm{rb}$ & $26,30 \mathrm{ra}$ & $26,63 \mathrm{ra}$ & 26,19 \\
\hline & & xa & $\mathrm{yb}$ & $\mathrm{zb}$ & a \\
\hline & Rerata & $26,08 \mathrm{a}$ & $25,74 \mathrm{a}$ & $25,19 \mathrm{~b}$ & $(+)$ \\
\hline
\end{tabular}

Interaksi optimum terjadi pada semua pengamatan jumlah daun yakni pada perlakuan kultivar buah bulat kecil dengan perlakuan mulsa plastik.

\section{Luas Daun}

Interaksi antara perlakuan kultivar dan pemberian mulsa yakni pada pengukuran luas daun disetiap pengamatan menunjukan beda sangat nyata.
Tabel 7. Luas Daun $\left(\mathrm{cm}^{2}\right)$

\begin{tabular}{|c|c|c|c|c|}
\hline \multirow[b]{2}{*}{ Mulsa } & \multicolumn{3}{|c|}{ Kultivar } & \multirow[b]{2}{*}{ Rerata } \\
\hline & Buah Bulat Kecil & $\begin{array}{c}\text { Buah Bulat } \\
\text { Besar }\end{array}$ & $\begin{array}{c}\text { Buah Bulat } \\
\text { Panjang }\end{array}$ & \\
\hline \multirow{2}{*}{ Tanpa } & $1861,07 \mathrm{pb}$ & 2048,06 pa & $1913,40 \mathrm{pb}$ & 1940,84 \\
\hline & xab & ya & $\mathrm{za}$ & $\mathrm{a}$ \\
\hline \multirow{2}{*}{$\begin{array}{l}\text { Plastik } \\
\text { Hitam }\end{array}$} & $1944,63 \mathrm{qb}$ & $2180,80 \mathrm{qa}$ & $2013,73 \mathrm{qb}$ & 2046,39 \\
\hline & $\mathrm{xb}$ & $\mathrm{yb}$ & zab & b \\
\hline \multirow{2}{*}{$\begin{array}{l}\text { Alang- } \\
\text { Alang }\end{array}$} & $1814,90 \mathrm{rb}$ & $2081,40 \mathrm{ra}$ & $2102,56 \mathrm{ra}$ & 1999,62 \\
\hline & xa & yab & $\mathrm{zb}$ & $a b$ \\
\hline Rerata & $1873,53 \mathrm{c}$ & $2103,42 \mathrm{a}$ & $2009,90 \mathrm{~b}$ & $(+)$ \\
\hline Keterangan: & \multicolumn{4}{|c|}{$\begin{array}{l}\text { Angka pada kolom dan baris diikuti huruf sama tidak berbeda pada } \\
\text { taraf nyata }(\alpha) 5 \% \text { menurut uji DMRT } \\
(+)=\text { Terjadi interaksi antar perlakuan }\end{array}$} \\
\hline
\end{tabular}

Hasil pengamatan menunjukan bahwa interaksi optimum antara perlakuan kultivar buah bulat besar dengan pemberian mulsa plastik hitam, antara perlakuan kultivar Fua Bubu Mnanu dengan pemberian mulsa alang-alang, dan antara perlakuan kultivar buah bulat kecil dengan perlakuan mulsa plastik hitam.

\section{Berat Kering Berangkasan}

Interaksi antara kultivar pada penimbangan berat kering berangkasan menunjukkan beda nyata antara perlakuan kultivar buah bulat panjang dengan pemberian mulsa alang-alang.

Interaksi optimum terjadi pada perlakuan kultivar buah bulat besar dengan pemberian mulsa alang-alang.

Tabel 8. Berat Kering Berangkasan (t/ha)

\begin{tabular}{|c|c|c|c|c|}
\hline \multirow[b]{2}{*}{ Mulsa } & \multicolumn{3}{|c|}{ Kultivar } & \multirow[b]{2}{*}{ Rerata } \\
\hline & Buah Bulat Kecil & $\begin{array}{c}\text { Buah Bulat } \\
\text { Besar }\end{array}$ & $\begin{array}{c}\text { Buah Bulat } \\
\text { Panjang }\end{array}$ & \\
\hline \multirow{2}{*}{ Tanpa } & 9,33 ра & $8,31 \mathrm{pab}$ & $6,37 \mathrm{pb}$ & 8,00 \\
\hline & xa & ya & za & $\mathrm{a}$ \\
\hline \multirow{2}{*}{$\begin{array}{l}\text { Plastik } \\
\text { Hitam }\end{array}$} & 10,17 qa & 7,48 qa & 7,47 qa & 8,37 \\
\hline & xa & ya & $\mathrm{za}$ & $\mathrm{a}$ \\
\hline \multirow{2}{*}{ Alang-Alang } & $9,24 \mathrm{ra}$ & $11,09 \mathrm{ra}$ & $10,09 \mathrm{ra}$ & 10,14 \\
\hline & xa & ya & $\mathrm{za}$ & $\mathrm{a}$ \\
\hline Rerata & $9,58 \mathrm{a}$ & $8,96 a b$ & $7,98 \mathrm{~b}$ & $(+)$ \\
\hline Keterangan: & $\begin{array}{l}\text { Angka pada kolom } \\
\text { taraf nyata }(\alpha) 5 \% \\
(+)=\text { Terjadi intera }\end{array}$ & $\begin{array}{l}\text { an baris diikuti } \\
\text { enurut uji DMR } \\
\text { i antar perlakua }\end{array}$ & f sama tidak b & eda pada \\
\hline
\end{tabular}

\section{Jumlah Buah}

Interaksi antara kultivar pada pengamatan jumlah daun tidak beda nyata dengan pemberian mulsa pada setiap waktu panen.

$\underline{\text { Tabel 9. Jumlah Buah }}$

\begin{tabular}{|c|c|c|c|c|c|}
\hline \multirow[b]{2}{*}{ Waktu } & \multirow[b]{2}{*}{ Mulsa } & \multicolumn{3}{|c|}{ Kultivar } & \multirow[b]{2}{*}{ Rerata } \\
\hline & & $\begin{array}{c}\text { Buah Bulat } \\
\text { Kecil }\end{array}$ & $\begin{array}{c}\text { Buah Bulat } \\
\text { Besar }\end{array}$ & $\begin{array}{c}\text { Buah Bulat } \\
\text { Panjang }\end{array}$ & \\
\hline \multirow{7}{*}{90 HST } & \multirow{2}{*}{ Tanpa } & $41 \mathrm{pa}$ & $47 \mathrm{pa}$ & $41 \mathrm{pa}$ & 43 \\
\hline & & xa & ya & $\mathrm{za}$ & $\mathrm{a}$ \\
\hline & \multirow{2}{*}{$\begin{array}{l}\text { Plastik } \\
\text { Hitam }\end{array}$} & $44 \mathrm{qa}$ & $45 \mathrm{qa}$ & $45 \mathrm{qa}$ & 44 \\
\hline & & xa & ya & $\mathrm{za}$ & $\mathrm{a}$ \\
\hline & \multirow{2}{*}{$\begin{array}{l}\text { Alang- } \\
\text { Alang }\end{array}$} & $60 \mathrm{ra}$ & $57 \mathrm{ra}$ & $64 \mathrm{ra}$ & 60 \\
\hline & & $x b$ & $\mathrm{yb}$ & $\mathrm{zb}$ & b \\
\hline & Rerata & $49 \mathrm{a}$ & $50 \mathrm{a}$ & $50 \mathrm{a}$ & $(+)$ \\
\hline \multirow{7}{*}{$\begin{array}{r}100 \\
\text { HST }\end{array}$} & \multirow{2}{*}{ Tanpa } & $36 \mathrm{pa}$ & $42 \mathrm{pa}$ & $36 \mathrm{pa}$ & 38 \\
\hline & & xa & ya & $\mathrm{za}$ & $\mathrm{a}$ \\
\hline & \multirow{2}{*}{$\begin{array}{l}\text { Plastik } \\
\text { Hitam }\end{array}$} & 39 qa & $40 \mathrm{qa}$ & $40 \mathrm{qa}$ & 39 \\
\hline & & xa & ya & $\mathrm{za}$ & a \\
\hline & \multirow{2}{*}{$\begin{array}{l}\text { Alang- } \\
\text { Alang }\end{array}$} & $55 \mathrm{ra}$ & $52 \mathrm{ra}$ & $59 \mathrm{ra}$ & 55 \\
\hline & & $\mathrm{xb}$ & $\mathrm{yb}$ & $\mathrm{zb}$ & b \\
\hline & Rerata & $44 \mathrm{a}$ & $45 \mathrm{a}$ & $45 \mathrm{a}$ & $(+)$ \\
\hline Keteran & \multicolumn{5}{|c|}{$\begin{array}{l}\text { Angka pada kolom dan baris diikuti huruf sama tidak berbeda pada } \\
\text { taraf nyata }(\alpha) 5 \% \text { menurut uji DMRT } \\
(+)=\text { Terjadi interaksi antar perlakuan }\end{array}$} \\
\hline
\end{tabular}

Interaksi optimum pada pengamatan jumlah buah terjadi antara perlakuan kultivar buah bulat panjang dengan pemberian mulsa alang-alang.

\section{Berat Buah}

Interaksi antara kultivar pada penimbangan berat buah menunjukan tidak berbeda nyata pada pemberian mulsa pada disetiap waktu panen.

Interaksi optimum terjadi antara perlakuan kultivar buah bulat panjang dengan pemberian mulsa alang-alang. 
Tabel 10. Berat Buah (t/ha)

\begin{tabular}{|c|c|c|c|c|c|}
\hline \multirow[b]{2}{*}{ Waktu } & \multirow[b]{2}{*}{ Mulsa } & \multicolumn{3}{|c|}{ Kultivar } & \multirow[b]{2}{*}{ Rerata } \\
\hline & & $\begin{array}{c}\text { Buah Bulat } \\
\text { Kecil }\end{array}$ & $\begin{array}{c}\text { Buah Bulat } \\
\text { Besar }\end{array}$ & $\begin{array}{c}\text { Buah Bulat } \\
\text { Panjang }\end{array}$ & \\
\hline \multirow{7}{*}{90 HST } & \multirow{2}{*}{ Tanpa } & $12,14 \mathrm{pa}$ & 13,89 pa & $11,95 \mathrm{pa}$ & 12,66 \\
\hline & & xa & ya & $\mathrm{za}$ & a \\
\hline & \multirow{2}{*}{$\begin{array}{l}\text { Plastik } \\
\text { Hitam }\end{array}$} & $12,97 \mathrm{qa}$ & $13,06 \mathrm{qa}$ & $13,06 \mathrm{qa}$ & 13,03 \\
\hline & & xa & ya & $\mathrm{za}$ & $a b$ \\
\hline & \multirow{2}{*}{$\begin{array}{l}\text { Alang- } \\
\text { Alang }\end{array}$} & $17,60 \mathrm{rab}$ & $16,68 \mathrm{rb}$ & $18,70 \mathrm{ra}$ & 17,66 \\
\hline & & $\mathrm{xb}$ & ya & $\mathrm{zb}$ & b \\
\hline & Rerata & $14,24 \mathrm{a}$ & $14,54 \mathrm{a}$ & 14,57 a & $(+)$ \\
\hline \multirow{7}{*}{$\begin{array}{c}100 \\
\text { HST }\end{array}$} & \multirow{2}{*}{ Tanpa } & $9,56 \mathrm{pa}$ & $9,64 \mathrm{pa}$ & $9,64 \mathrm{pa}$ & 9,61 \\
\hline & & xa & ya & $\mathrm{za}$ & a \\
\hline & \multirow{2}{*}{$\begin{array}{l}\text { Plastik } \\
\text { Hitam }\end{array}$} & 6,03 qa & 7,78 qa & $5,84 \mathrm{qa}$ & 6,55 \\
\hline & & xa & ya & $\mathrm{za}$ & $\mathrm{a}$ \\
\hline & \multirow{2}{*}{$\begin{array}{l}\text { Alang- } \\
\text { Alang }\end{array}$} & $14,14 \mathrm{ra}$ & $13,22 \mathrm{ra}$ & $15,24 \mathrm{ra}$ & 14,20 \\
\hline & & $\mathrm{xb}$ & $\mathrm{yb}$ & $\mathrm{zb}$ & $\mathrm{b}$ \\
\hline & Rerata & $9,91 \mathrm{a}$ & $10,21 \mathrm{a}$ & $10,24 \mathrm{a}$ & $(+)$ \\
\hline Keterang & \multicolumn{5}{|c|}{$\begin{array}{l}\text { Angka pada kolom dan baris diikuti huruf sama tidak berbeda pada } \\
\text { taraf nyata }(\alpha) 5 \% \text { menurut uji DMRT } \\
(+)=\text { Terjadi interaksi antar perlakuan }\end{array}$} \\
\hline
\end{tabular}

Tabel 11. Indeks Panen (\%)

\begin{tabular}{|c|c|c|c|c|}
\hline \multirow[b]{2}{*}{ Mulsa } & \multicolumn{3}{|c|}{ Kultivar } & \multirow[b]{2}{*}{ Rerata } \\
\hline & Buah Bulat Kecil & $\begin{array}{c}\text { Buah Bulat } \\
\text { Besar }\end{array}$ & $\begin{array}{c}\text { Buah Bulat } \\
\text { Panjang }\end{array}$ & \\
\hline \multirow{2}{*}{ Tanpa } & $37,17 \mathrm{~b}$ & $41,66 \mathrm{a}$ & $40,49 \mathrm{~b}$ & 39,78 \\
\hline & xa & ya & $\mathrm{zb}$ & $a b$ \\
\hline \multirow{2}{*}{$\begin{array}{l}\text { Plastik } \\
\text { Hitam }\end{array}$} & $37,79 \mathrm{~b}$ & 41,17 a & $30,46 \mathrm{~b}$ & 36,48 \\
\hline & xa & yа & $\mathrm{za}$ & $\mathrm{a}$ \\
\hline \multirow{2}{*}{$\begin{array}{l}\text { Alang- } \\
\text { Alang }\end{array}$} & $46,33 \mathrm{~b}$ & $42,86 \mathrm{~b}$ & $46,82 \mathrm{a}$ & 45,34 \\
\hline & $\mathrm{xb}$ & ya & $\mathrm{zc}$ & $\mathrm{b}$ \\
\hline Rerata & $40,43 \mathrm{~b}$ & $41,90 \mathrm{a}$ & $39,26 \mathrm{~b}$ & $(+)$ \\
\hline Keterangan: & $\begin{array}{l}\text { Angka pada kolom } \\
\text { taraf nyata }(\alpha) 5 \% \\
(+)=\text { Terjadi intera }\end{array}$ & $\begin{array}{l}\text { aris diikuti h } \\
\text { rut uji DMRT } \\
\text { tar perlakuan }\end{array}$ & ma tidak be & pada \\
\hline
\end{tabular}

\section{Pembahasan}

Hasil analisis data parameter penelitian menunjukan bahwa perlakuan penanaman kultivar terung lokal dan perlakuan pemberian mulsa berpengaruh nyata pada suhu tanah, kadar lengas tanah, berat volume tanah, tinggi tanaman pada pengamatan 45 HST, jumlah daun, luas daun, berat berangkasan dan indeks panen.

Suhu pada lahan yang ditutupi plastik hitam maupun alang-alang sejak awal lebih lebih rendah sejalan ,dengan kadar lengas yang terjadi lebih tinggi dan menggambarkan ketersediaan air bagi tanaman maksimal akibatnya perlakuan pemberian mulsa berpengaruh nyata pada berat volume tanah. Terlihat bahwa penanaman kultivar terung bulat besar pada lahan yang ditutupi plastik hitam terdapat berat volume tanah yang optimal nilainya bagi petumbuhan tanaman namun tidak berbeda nyata dengan kultivar bulat panjang pada lahan yang ditutupi mulsa alang-alang. Berat volume tanah menggambarkan terciptanya suatu kondisi yang baik bagi keluar masuknya udara maupun air dari tanah menuju tanaman. Hal ini mengakibatkan porositas tanah lebih baik bagi keluar masuknya air dan udara secara bebas sehingga tanaman tumbuh lebih tinggi, meningkatnya luas daun, akibatnya fotosintesis bagi pertumbuhan vegetatif berjalan baik yang pada akhirnya mendukung pertumbuhan generatif.

Penanaman kultivar bulat besar pada lahan yang ditutupi plastik hitam maupun penanaman kultivar bulat panjang pada lahan yang ditutupi alang-alang sejak awal pertumbuhannya berjalan dalam lingkungan yang optimal sehingga respon fisiologis tanaman menghasilkan berat kering berangkasan yang paling berat, dengan rasio berat segar tanaman yang bernilai ekonomis dan bagian segar tanaman yang tidak bernilai ekonomis tidak berbeda terlalu jauh, akibatnya indeks panen pada penen I yang dihasilkan paling tinggi dan berbeda sangat nyata dengan perlakuan kombinasi lainya. Dan diketahui bahwa indeks panen cenderung meningkat dari panen I hingga pada panen II. Pada panen II selisih berat buah dan berat berangkasan tidak terlalu jauh berbeda sehingga indeks panen pun meningkat.

\section{Simpulan}

a. Dengan semakin lama penggunaan mulsa nilai berat volume tanah semakin menurun, indikasi bahwa porositas tanah semakin meningkat.

b. Pada budidaya tanpa menggunakan mulsa maupun menggunakan mulsa plastik hitam kultivar terung buah bulat besar (Fua bubu naek) memiliki adaptasi yang lebih baik.

c. Ketiga kultivar terung lokal hasilnya meningkat lebih tinggi bila menggunakan mulsa alang-alang, dan kultivar buah bulat panjang (Fua bubu mnanu) hasilnya paling tinggi.
Daftar Pustaka

Adji, 2000. Rancangan Percobaan Praktis Bidang Pertanian. Kanisius, Yogyakarta.

BPS Kabupaten Timor Tengah Utara, 2007. Kabupaten TTU dalam Angka. BPS Kabupaten Timor Tengah Utara, Kefamenanu.

Hanafiah, 2005. Rancangan Percobaan Aplikatif. P.T. Raja Grafindo Persada, Jakarta.

Hastuti, L. D. 2007. Terung: Tinjauan Langsung Ke Beberapa Pasar Tradisonal Di Kota Bogor. Tesis; Fakultas Matematika dan Ilmu Pengetahuan Alam Universitas Sumatra Utara.

Noorhadi dan Sudadi, 2003. Kajian Pemberian Air dan Mulsa terhadap Iklim Mikro pada Tanaman Cabai di Tanah Entisol. Fakultas Pertanian UNS Surakarta. Jurnal Ilmu Tanah dan Lingkungan, 4(1): 41-49

Rukmana, 1994. Bertanam Terung. Kanisius, Yogyakarta.

Samadi, 2001. Budi Daya Terung Hibrida, Kanisius, Yogyakarta. 